\title{
Correction to: An International Comparison of Financial Consumer Protection
}

\author{
Tsai-Jyh Chen
}

Correction to:

T.-J. Chen (ed.), An International Comparison

of Financial Consumer Protection, https://doi.org/10.1007/978-981-10-8441-6

The original version of the book was inadvertently published without including the copyright comment "The print edition is not for sale in the Republic of Korea. Customers from the Republic of Korea please order the print book from: PnC media (ISBN: 979-11-5730-571-1)" in the copyright page (iv) of Frontmatter. The book has been now updated with the change.

The updated online version of this book can be found at https://doi.org/10.1007/978-981-10-8441-6 